Szent János Kórház és Észak-budai Egyesített Intézetei, II. Belgyógyászat-Diabetológia, az SE ÁOK oktató- és gyakorlóosztálya, Budapest, ${ }^{1}$ Miskolci Egyetem Egészségügyi Kar, Miskolc, Elméleti Egészségtudományi Intézet ${ }^{2}$

\title{
A bázisinzulin-kezelés „intenzifikálásának" hagyományos oldala - a napszakos inzulinkezelés lépcsőzetes bevezetési lehetőségei 2-es típusú diabetesben
}

\author{
Winkler Gábor dr. ${ }^{(1,2)}$
}

\begin{abstract}
Összefoglalás
Számos megfigyelés támasztja alá, hogy ha a kivánt anyagcserekontroll orális antidiabetikus kezeléssel már nem biztositható, bázisinzulin, bázisinzulin mellé adott prandialis inzulin szekvenciális (lépcsözetes) bevezetése („, bázis plusz" kezelés), vagy ezek alternativájaként, elökevert inzulinanalóg napi egy vagy két alkalommal történö adása is elegendö lehet 2-es típusú diabetesben. A közlemény az e kezelésekkel kapcsolatos irodalmi adatokat tekinti át. A vizsgálatok azt igazolják, hogy e kezelésformák hatékonyak, biztonságosak, a beállitás ambulanter is elvégezhetö. Hazai alkalmazásukat ez idö szerint finanszirozási korlátok nehezitik, ezek módosulásával azonban bevezetésük - az azonnali hagyományos, teljes bázis-bólus kezelési rendszerre való áttérés alternativ lehetöségeként - bövitheti az egyénre adaptált vércukorcsökkentö kezelés eszköztárát.

Kulcsszavak: 2-es típusú diabetes, bázis plusz kezelés, elökevert inzulinanalóg napi egy-háromszori adása

\section{Strategies for stepwise initiation of insulin in type 2 diabetes - the "traditional" mode of insulinisation after failure with oral antidiabetics}

Summary: Numerous observations support, that in failure of glycemic control with oral antidiabetics in type 2 diabetes, the stepwise initiation of insulin (basal insulin, basal plus therapy or as an alternative route, initiation of analogue premix insulins) is an effective choice for improving metabolic state. Many patients do not need daytime insulin already at the beginning, one or two injections may be sufficiently efficient for shorter-longer time. The article overviews experiences of these therapies. The studies and metaanalyses confirm, that stepwise initiation of insulin is effective, safe and can be performed in outpatient setting. Their application in the present Hungarian practice are restricted because of financial barriers, however, with the modification of these hurdles, as an alternative of the traditional basis-bolus therapy, they offer further possibilities to individually tailored antidiabetic therapy.
\end{abstract}

Keywords: type 2 diabetes, basal plus therapy, analogue premix insulin daily once-two times

Rövidítések

AACE: Amerikai Klinikai Endokrinológiai Szövetség (American Association of Clinical Endocrinologists); ACE: Amerikai Endokrinológiai Kollégium (American College of Endocrinology); ADA: Amerikai Diabetes Társaság (American Diabetes Association); BBT: bázis-bólus kezelés (basal-bolus treatment); BMI: testtömegindex (body mass index); BOT: bázisinzulinnal kiegészített orális kezelés (basal [insulin] supplemented oral therapy); CDA: Kanadai Diabetes Társaság (Canadian Diabetes Association); Cl: megbízhatósági tartomány (confidence interval); DPP-4: dipeptidilpeptidáz-4; E: egység; EASD: Európai Diabetes Társaság (European Association for the Study of Diabetes); GLP-1: glukagonszerü peptid (glucagon-like peptide)-1; IDF: Nemzetközi Diabetes Szövetség (International Diabetes Fed- 
eration); PM: premix [inzulin]; PM25, PM50: 25/75, illetve 50/50 keverékarányú premix inzulin; pp: postprandialis; PPT: prandialis premix kezelés (prandial premix treatment); SGLT-2: nátrium-glukóz kotranszporter (sodium-glucose cotransporter)-2; SMBG: vércukor-önellenörzés (self-monitoring of blood glucose); T2DM: 2-es típusú cukorbetegség (type 2 diabetes mellitus); TZD: tiazolidindion

A 2-es típusú diabetes (T2DM) progresszív betegség. A kívánt glykaemiás kontroll elérése és fenntartása - a genetikailag determinált inzulinszekréciós kapacitás és az inzulinrezisztencia mértéke függvényében - egyénenként változó időtartamot követően az esetek túlnyomó többségében inzulin adását (is) igényli. ${ }^{1,2}$

A napközbeni vércukorértékek emelkedése nem-inzulintermészetű készítményekkel általában jól kezelhető, a célérték fölötti éhomi vércukorszint azonban ily módon nem minden esetben rendezhető. Ez a magyarázata, hogy az inzulin bevezetése e kórformában leggyakrabban az orális kezelés kiegészítéseként adagolt bázisinzulin formájában történik (BOT). Ha azután a nap során mért értékek - újra - emelkednek, a kezelés „intenzifikálásának" hagyományos útját a napszakos inzulinadás valamely formájára való áttérés jelentheti, ${ }^{3}$ míg a kezelés alternatív lehetőségeként bázisinzulin mellé adott dipeptidilpeptidáz (DPP)-4gátló, glukagonszerű peptid (GLP)-1-mimetikum vagy nátrium-glukóz kotranszporter (SGLT)-2gátló bevezetése, esetleg a felsoroltak kombinálása jöhet szóba. ${ }^{4}$

A jelen munkánknak nem tárgya a két kezelési út előnyeinek/korlátainak vagy a választásukat alátámasztó lehetséges szempontoknak számbavé- tele. A napszakos inzulinadás bevezetésének szekvenciális lehetőségeit, a „bázis plusz” koncepciót, illetve a lépcsőzetesen adagolt premix inzulinanalóg-kezeléssel kapcsolatos adatokat tekintjük át.

\section{A (napszakos) inzulinadás korlátai}

Számos megfigyelés támasztja alá, hogy a kívánt glykaemiás kontrollt biztosító kezelésváltás a T2DM egész tartama alatt késik. ${ }^{5}$ Különösen igaz ez a bázisinzulin-adás ,intenzifikálását” igénylő időszakra: az Egyesült Államokból származó, 14457 személy adatait feldolgozó elemzés szerint két évvel a BOT (a hazai terminológiában meghonosodott, helytelen szóhasználattal: BOT kezelés) bevezetése után mindössze az érintettek 29\%ának $\mathrm{HbA}_{1 \mathrm{c}}$-értéke $<7,0 \%,{ }^{6} \mathrm{~s}$ nem jobb a helyzet Európában sem. Az Egyesült Királyságban 3185 T2DM-es személy átlagosan 2,9 éves követésének feldolgozásakor azt találták, hogy az e kezelésre állítottak 60\%-ának anyagcsere-állapota érdemben nem változott, e csoport átlagos $\mathrm{HbA}_{1 c}$-értéke a feldolgozás lezárásakor $8,1 \%$ volt. ${ }^{7}$ A 2005-ben közzétett Diabetes Attitudes, Wishes and Needs (DAWN) vizsgálat is azt erősítette meg, hogy a cukorbetegekkel foglalkozó orvosok 50-55\%-a a

1. táblázat. Inzulinkezelés bevezetésének és „intenzifikálásának" az érintett személy (és környezete), illetve a kezelést folytatók oldaláról felmerülő lehetséges korlátai

\begin{tabular}{|c|c|}
\hline Az érintett személyek oldaláról & A kezelésben részt vevők oldaláról \\
\hline \multicolumn{2}{|c|}{ A kezelés bevezetését hátráltató attitüd } \\
\hline $\begin{array}{l}\text { - az inzulinkezelés szükségessége személyes kudarc, az orvosi } \\
\text { utasítások nem megfelelő követésének eredménye } \\
\text { • az inzulinadás elkezdése az addigi életvezetés teljes megváltoztatását } \\
\text { igényli }\end{array}$ & $\begin{array}{l}\text { • sikerül-e az adott személy számára legmegfelelőbb kezelési } \\
\text { rendszer megtalálása } \\
\text { • kellően járatos-e a beteg addigi ellenőrzését végző team a } \\
\text { választandó kezelésben }\end{array}$ \\
\hline \multicolumn{2}{|c|}{ A kezelés „intenzifikálásával" kapcsolatos korlátok } \\
\hline $\begin{array}{l}\text { - félelem a nem kívánt vércukoresésektől } \\
\text { - félelem a hízástól } \\
\text { - félelem a gyakoribb vércukor-önellenőrzés kényelmetlenségeitől } \\
\text { • félelem az ellenőrzést végző teamtől való szorosabb kapcsolattól, } \\
\text { "függőségtől" }\end{array}$ & $\begin{array}{l}\text { - a kezelés elsajátításához szükséges betegoktatás időigényesebb } \\
\text { volta } \\
\text { • gyakoribb kontroll szükségessége }\end{array}$ \\
\hline
\end{tabular}


szükségesnél később kezdi/kezdené el az inzulin adagolását. ${ }^{8}$
Az inzulinkezeléssel, valamint a már megkezdett inzulinadás „intenzifikálásával” kapcsolatos

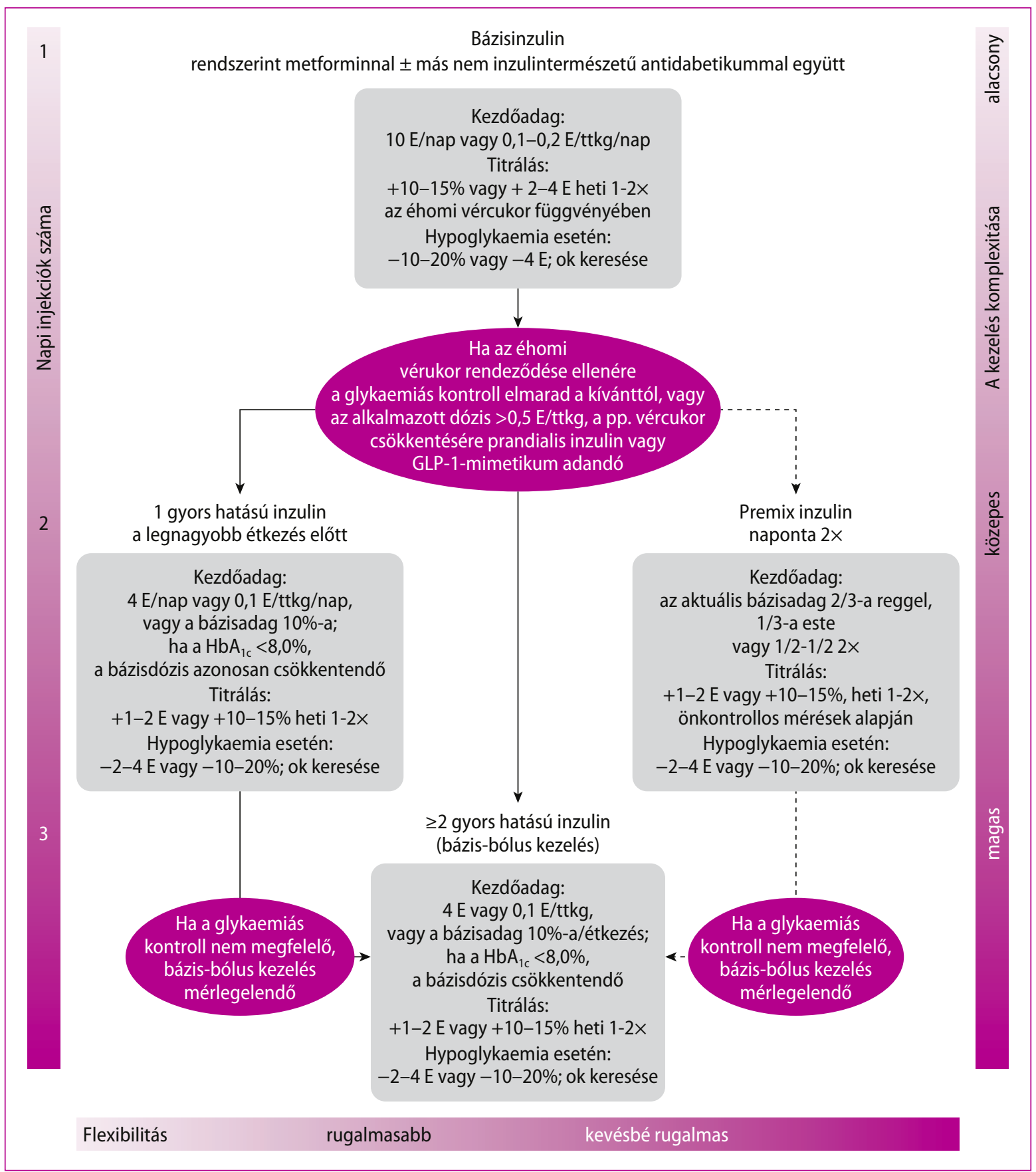

1. ábra. Az inzulinkezelés bevezetési lehetőségei 2-es típusú diabetesben az ADA-EASD 2015. évi ajánlása szerint (Inzucchi SE et al. ${ }^{12}$ - a kiadó engedélyével) 
félelmek és korlátok mára jól körvonalazottak (1. táblázat). E gátak leküzdésére kínál alternatívát a napszakos inzulinadás fokozatos bevezetése. A bázisinzulinhoz adott napi egy, majd szükség szerint bővítve további prandialis inzulinanalóg, vagy helyettük analóg premix készítmény fokozatos bevezetése és szükség szerinti gyakoriságú (napi 1-3 alkalommal) adagolása kisebb inzulinadagot jelent, mint ha az áttérés egy lépésben történik. Ritkábbá válhat ezáltal a hypoglykaemia előfordulása és a súlygyarapodás is jobban kontrollálható. A kezelési rendszerek egy része lehetővé teszi a beteg általi dózisfelépítést is, megerősítve benne a kezelését/ellenőrzését végzőktől való függetlenség érzetét és az önmenedzselés képességét. ${ }^{1,2,3,8,9}$

\section{A „bázis plusz" kezelési koncepció}

A szekvenciális inzulinadás eredményességéről, $1,2,10$ biztonságáról ${ }^{1,2,3}$ és a betegek oldaláról mutatkozó kedvezőbb elfogadásáról',10 2008-tól kezdve jelentek meg közlemények. Módszertani ajánlásban az inzulin bevezetésének lehetséges alternatívájaként először az Amerikai (ADA) és az Európai Diabetes Társaságnak (EASD) a T2DM vércukorcsökkentő kezelésével foglalkozó, 2012. évi közös útmutatásában jelent meg, ${ }^{11}$ a 2015-ben megújított irányelv azután részletes metodikai útmutatással is szolgált (1. ábra). ${ }^{12}$ Ennek nyomán vált általánosan elfogadottá a „bázis plusz”, illetve további lépéseként a „bázis két plusz” elnevezés is.

A „bázis plusz” koncepció azt jelenti, hogy az éhomi és preprandialis vércukorszint kezelési célértékének bázisinzulin-analóggal való biztosítását követően az egyes étkezések - nem-inzulintermészetű antidiabetikumokkal kellően nem befolyásolható - vércukoremelő hatásának ellensúlyozására prandialis inzulinanalógot vezetnek be. Az esetek egy részében - kezdetben - elegendő lehet a legnagyobb vércukor-emelkedést okozó étkezés előtti inzulinadás, ezt követheti szükség szerint egy második étkezéshez adagolt gyors hatású inzulin bevezetése („bázis két plusz” kezelés), majd a hagyományos bázis-bólus elvű rendszerre való áttérés. E koncepció lehetővé teszi, hogy a napszakos inzulinadás is a T2DM vércukorcsökkentő kezelését általában jellemző szekvenciális módon történjen, elkerülhetővé váljon a szükségesnél gya- koribb és nagyobb adagú inzulinbevitel, javuljon a betegek együttműködési készsége és kezelés iránti elfogadása. Gyakorlati alkalmazását a humán inzulinokétól eltérő hatásdinamikájú, korszerű inzulinok széles választékának hozzáférhetővé válása tette lehetővé (2. táblázat).

A „bázis-plusz” koncepció további előnye, hogy flexibilitást biztosít különböző életvezetésű, étkezési-szociális kultúrájú csoportoknak az első prandialis inzulin bevezetése tekintetében. Nem kétséges, hogy a legkifejezettebb postprandialis (pp.) vércukor-emelkedés a legnagyobb szénhidráttartalmú étkezés után várható. Jól ismert azonban, hogy e hyperglykaemia mértékét befolyásolja az étkezés időpontja (az inzulinérzékenység napszakos változása), tartama, valamint a fogyasztott táplálék összetétele. A mediterrán országokban - ahol a reggeli és az ebéd szénhidráttartalma általában kisebb az esti, egyben családi-társasági esemény szerepét is betöltő, gyakran késői kezdetű és időben elhúzódó vacsora a fó étkezés. Az angolszász országokban viszont igen hangsúlyos a nap első étkezése, a reggeli („English breakfast”), ráadásul szokásos időpontjában, reggel 7.00 óra után már az inzulinérzékenység is alacsonyabb, aminek eredményeként kisebb szénhidrátmennyiség is nagy pp. vércukor-emelkedést okozhat. A cukorbetegek egy csoportja - a nem cukorbetegekkel egyezően - a reggelit változó időben fogyasztja vagy kihagyja, ${ }^{3}$ esetenként a kimaradt étkezés szénhidráttartalmát - a dietoterápiás ajánlásokkal dacolva - egy későbbi főétkezésnél pótolja. A napszakos inzulinkezelés hatékonyságát tehát számos beteg-függő és -független tényező befolyásolja, amit a kezelési rendszer megtervezésekor figyelembe kell venni.

A „bázis plusz” koncepció jegyében fogant tanulmányok egy része a lépcsőzetes bevezetésủ és a kezdettől fogva teljes dózisú napszakos inzulinadás hatékonyságát veti össze, más része különböző - orvos- illetve beteg irányította, vagy betegek által végzett eltérő rendszerű - titrálási algoritmusok megbízhatóságát és hatékonyságát elemzi.

A 7 ország 150 vizsgálóhelyének részvételével folytatott 32 hetes, IV. fázisú, párhuzamos karú, aktív kontrollcsoportos, treat-to-target felépítésű, nyílt követésű FullSTEP vizsgálatot a „bázis plusz” kezelés „bázis-bólus” rendszerhez viszonyított non-inferior voltának igazolására indították. ${ }^{13}$

Az 1:1 randomizációjú vizsgálatba olyan bázisinzulin \pm orális antidiabetikus kezelés alatt álló személyeket vontak be, akik $\mathrm{HbA}_{1 \mathrm{c}}$-értéke 7,0-9,0\% közötti volt. A randomizált 401, $59,8 \pm 9,3$ éves korú, 12,6 \pm 8,0 év ismert diabetestartamú sze- 
mély közül 200 került a „bázis-bólus”, 201 a „bázis plusz” kezelési ágra. Ez utóbbiban a prandialis bólust kezdetben a legnagyobb napi étkezés előtt adták. A vizsgálat 8 hetes bevezető (run-in) fázisa a bázisinzulin (detemir) szolgált, a bázisinzulint lefekvéskor adagolták. A titrálást a TITRATE vizsgálatban leírtak szerint végezték. ${ }^{14}$ Ezt követően, a bázis plusz csoportban a legnagyobb napi étkezés előtt $4 \mathrm{E}$ prandialis inzulint (aspart) indítottak, míg a bázis-bólus ágon minden étkezés előtt 2-2 E gyors hatású inzulint adagoltak. Az aspart inzulin titrálása mindkét kezelési csoportban a következő étkezés vagy a lefekvés előtti vércukorszint alapján történt. A bázis plusz karon a 11. héttől kezdve egy további prandialis inzulin is bevezetésre került (a második legnagyobb napi étkezés előtt adva), ha a $\mathrm{HbA}_{1 \mathrm{c}}$-érték $\geq 7,0 \%$ maradt. A dózistitrálás folytatódott, $\mathrm{s}$ ha a $\mathrm{HbA}_{1 \mathrm{c}}$-érték a 22 . hétre sem csökkent célértékre, a bázis plusz kezelést folytatóknál egy harmadik étkezési inzulin hozzáadására is sor került.

A követés lezárásakor a lépcsőzetes inzulinadagolást folytatók $\mathrm{HbA}_{1 \mathrm{c}}$-értéke -0,98\%-kal csökkent (95\%-os megbízhatósági határ [confidence interval: $\mathrm{CI}]-1,09--0,87)$, ugyanez a másik ágon $-1,12 \%(-1,23--1,0)$ volt. A két kar között 0,14\%-os különbség mutatkozott $(-0,02-0,30)$, az eltérés nem szignifikáns $(p=0,0876)$, a non-inferioritás kritériuma teljesült. A lépcsőzetes adagolási ágon kevesebb hypoglykaemia fordult elő (a gyakoriság kockázata 0,58 [95\%-os CI $0,45-0,75$, $\mathrm{p}<0,0001])$ és valamivel alacsonyabb volt a napi inzulindózis is (aspart 0,5 E/kg, detemir $0,6 \mathrm{E} / \mathrm{kg}$ ), bár e különbség nem volt szignifikáns. E karon 28 beteg döntött a kezelés abbahagyása mellett, míg a másik ágon 52 személy fejezte be a vizsgálatot idő előtt. ${ }^{13}$

Több tanulmány vizsgálta célértékre (éhomi vércukor $\leq 5,5 \mathrm{mmol} / \mathrm{l}$ ) titrált dózisú bázisinzulin (glargin) mellé naponta egyszer adott prandialis bólus inzulin (glulisin) glykaemiás hatásának tartósságát. Az elemzések azt támasztották alá, hogy tekintet nélkül a vizsgálatba vontak életkorára és tápláltsági állapotára, e kezelés tartós anyagcsere-javulást biztosít, alacsony hypoglykaemia-kockázat és csak minimális súlygyarapodás mellett. E tanulmányok ugyanakkor a „bázis plusz” kezelés intenzifikálásának további lépéseit nem vizsgálták. ${ }^{6,15,16}$

\section{2. táblázat. A ma rendelkezésre álló humán, illetve inzulinanalóg-készítmények (Cahn et al. ${ }^{2}$ nyomán)}

\begin{tabular}{|c|c|c|c|c|}
\hline & & Hatáskezdet & Csúcshatás & Hatástartam \\
\hline Humán gyors hatású inzulin & Humán gyors hatású inzulin & $30-60$ perc & 2-4 óra & 5-8 óra \\
\hline \multirow{3}{*}{ Prandialis inzulinnalógok } & aspart & $12-18$ perc $^{* 1}$ & $30-90$ perc & $3-5$ óra \\
\hline & lispro & $15-30$ perc $^{* 1}$ & $30-90$ perc & 3-5 óra \\
\hline & glulisin & $12-30$ perc $^{* 1}$ & $30-90$ perc & 3-5 óra \\
\hline \multirow{2}{*}{ Intermedier hatású inzulinok*2 } & humán NPH & $60-120$ perc & 4-12 óra & 12-16 óra \\
\hline & protaminizált gyors hatású inzulinanalóg*3 & $30-60$ perc & 4-12 óra & 12-16 óra \\
\hline \multirow{4}{*}{ Bázisinzulin-analógok } & detemir & $60-120$ perc & 6-8 óra & -24 óra \\
\hline & glargin U100 & $60-120$ perc & nincs & 20-26 óra \\
\hline & glargin U300 & $60-120$ perc & nincs & -36 óra \\
\hline & degludek & $30-90$ perc & nincs & $>42$ óra \\
\hline \multirow{4}{*}{ Humán premix inzulinok ${ }^{* 4}$} & 15/85 keverék*5 & $30-60$ perc & 2-4 óra & 11-20 óra \\
\hline & 25/75 keverék & $30-60$ perc & 2-4 óra & 12-19 óra \\
\hline & 30/70 keverék & $30-60$ perc & 2-4 óra & 10-16 óra \\
\hline & 50/50 keverék $^{* 5}$ & $30-60$ perc & 2-5 óra & 10-16 óra \\
\hline \multirow{4}{*}{ Premix inzulinanalógok ${ }^{* 4}$} & 25/75 keverék & $10-15$ perc & 1-12 óra & 10-16 óra \\
\hline & 30/70 keverék & $15-30$ perc & 1-12 óra & 10-16 óra \\
\hline & 50/50 keverék & $15-30$ perc & 1-4 óra & 10-16 óra \\
\hline & 70/30 keverék ${ }^{* 5}$ & $5-15$ perc & 1-4 óra & 10-16 óra \\
\hline
\end{tabular}

*1 bár a táblázat az egyes prandialis analóg készítmények hatáskezdetében minimális eltérést jelöl, a gyakorlatban ennek nincs jelentősége. Éppen ezért, a 30/70, illetve 50/50 keverékarányú készítményeknél az eredeti táblázatban jelzett néhány percnyi - nem konzekvens - különbséget nem tüntettük fel

*22 bázishatás céljával adagolt, de nem valódi bázisinzulinok

*3 önállóan nincs forgalomban, keverék inzulinanalóg-készítmények elhúzódó hatású komponense

*4 az európai törzskönyvekben a gyors hatású komponens aránya szerepel elöl (a tengerentúli jelölés fordított)

*5 ez idő szerint nincs hazai forgalomban 
Csak a „bázis plusz” lépés eredményességét és biztonságát elemezte a Kanada 47 háziorvosi praxisában folytatott nyílt, randomizált, párhuzamos csoportú START (Self-Titration with Apidra to Reach Target) tanulmány. Újdonságát két, a kezelőorvos, illetve az érintett személy irányította (önmenedzselt) titrálási algoritmus eredményességének összehasonlítása jelentette. ${ }^{9}$

Bevonásra olyan $\geq 30$ éves T2DM-es személyek kerültek, akik önmagában vagy orális antidiabetikummal kombináltan alkalmazott bázisinzulinnal (glargin, napi 1-2-szer adagolt NPH, illetve detemir), illetve 2 vagy 3 orális antidiabetikummal a kívánttól elmaradó anyagcsere-állapotúak voltak $\left(\mathrm{HbA}_{1 \mathrm{c}}>7,0\right.$ [bázisinzulin csoport], illetve $\geq 7,8 \%$ [inzulinnaiv csoport]). A bázisinzulint is kapók a vizsgálatba vonáskor egységesen glargin inzulint kaptak, a korábban 1-szer NPH vagy detemir inzulint kapók azzal azonos dózisban, a 2-szer NPH-t adagolók az addigi napi összadag 80, a 2-szer detemirt injiciálók a korábbi napi összdózis $70 \%$-ában. Ezt követően, a run in szakasz 2 hetében az INSIGHT vizsgálat ${ }^{17}$ protokollja szerint naponként $1 \mathrm{E}$ dózisemelésre került sor a $\leq 5,5 \mathrm{mmol} / \mathrm{l}$ éhomi vércukor eléréséig. Az inzulint nem kapó személyek bázisinzulin-adagolása 10 E-gel indult, a dózisemelés azonos módon történt. Vizsgálóhelyenkénti 1:1 randomizációra azon személyek kerültek, akik $\mathrm{HbA}_{1 c}$-értéke a run in szakasz végén $>7,0 \%$ maradt és az utolsó héten legalább 1 igazolt éjszakai hypoglykaemiájuk (vércukor $<4,0 \mathrm{mmol} / \mathrm{l}$ ) volt, vagy a mért éhomi vércukorszint $\geq 2$ alkalommal $\leq 6,0 \mathrm{mmol} / \mathrm{l}$ volt. A beteg irányította titrálás során a kezdő prandialis inzulin (glulisin) adagja 2 E volt, amelyet reggeli előtt kellett adagolni. Ezt követően $1 \mathrm{E} /$ nap dózisemelésre került sor a reggeli után 2 órával mért 5,0-8,0 mmol/l vércukorszint eléréséig. A követés további szakaszában rendszeres pp. vércukormérést végeztek, dózisváltoztatásra csak akkor került sor, ha az értékek \pm irányban ismételten eltértek a célértéktől. Az orvos vezette titrálás ugyancsak 2 E-gel kezdődött, a dózisváltoztatás mértékét azonban a kezelőorvos határozta meg. Elsődleges végpontként a 24 . héten a csoportonként $<7,0 \% \mathrm{HbA}_{1 \mathrm{c}}$-értéket jelentős vércukoresések nélkül elérők arányát értékelték, másodlagos végpontként a hetenként mért 7 pontos vércukorprofil és a $\mathrm{HbA}_{1 \mathrm{c}}$-szint változásának adatait vizsgálták.

Azt találták, hogy a két titrálási ágon lévők között sem az anyagcserekontroll, sem a vércukoresések gyakorisága tekintetében nem volt különbség. Az öntitrálást folytatók 28,4 , az orvos vezette dózisemelést alkalmazók 21,2\%-a érte el a $<7,0 \%$ $\mathrm{HbA}_{1 \mathrm{c}}$-értéket jelentős vércukoresés nélkül. A két titrálási algoritmus egymáshoz viszonyított egyenértékű (non-inferior) természete igazolható volt. A szerzők vizsgálatuk korlátjaként értékelik az egységesen reggel és nem a legnagyobb napi étkezéshez igazított prandialis inzulinadást, amit az egyszerűség és az egységesítés könnyebbé tétele céljából alkalmaztak. Nem vizsgálták, hogy hogyan változhat az anyagcserehelyzet, ha további prandialis inzulinok adagolására is sor kerül. ${ }^{9}$

A lépcsőzetes inzulinadás különböző változatainak („bázis plusz”, „bázis két plusz”, bázis-bólus kezelés) hatékonyságát vetette össze Davidson és munkatársai 6 hónapos nyílt, párhuzamos karú tanulmánya. Követésükbe „inzulinnaiv” (inzulint korábban nem kapó), 2-3 orális antidiabetikummal a kívánttól elmaradó anyagcsere-állapotú $\left(\mathrm{HbA}_{1 \mathrm{c}}>8,0 \%\right)$ T2DM-es betegeket vontak be. ${ }^{18}$

A vizsgálatban részt vevő 18-79 éves személyek a követés megkezdése előtt metformint, sulfanylurea-típusú szert, illetve tiazolidindion (TZD) származékot szedtek kettes vagy hármas kombinációban, egyenként legalább a szokásos napi terápiás adag felét elérő dózisban. Kizárási feltételek (megelőző inzulinkezelés, metabolikus acidosis a kórelőzményben, károsodott veseműködés, TZD-t szedők esetében klinikailag szignifikáns perifériás oedema, infarktus vagy stroke a megelőző 12 hónapban, gyógyszeres kezelést igénylő keringési elégtelenség) hiányában a résztvevők napi 10 E kezdő dózisban glargin inzulint kaptak. Az adagot azután a két-kétnapi éhomi vércukorszint függvényében másodnaponta 0-2 E-gel emelték a megjelölt célértékig (3,9-5,5 mmol/l). E bevezető szakasz 14 hétig tartott. Ezt követően azon betegek esetében, akik $\mathrm{HbA}_{1 \mathrm{c}}$-értéke $>7,0 \%$ maradt, 1:1:1 arányú randomizáció szerint napi 1, 2 vagy 3 glulisin bólus adását kezdték. (Ez utóbbi csoport lényegében bázis-bólus elvủ kezelést jelentett, s e tekintetben a másik két csoport kontrolljaként szolgált.) A prandialis inzulin adagja minden esetben a randomizáció előtti glargindózis 1/10-e volt. A napi 1-szer glulisint kapók az inzulint a legnagyobb, a 2-szer injekciózók a két legnagyobb étkezés előtt 15-15 perccel adták. A prandialis inzulin hatékonyságát az inzulinadás utáni következő étkezés (tehát reggeli inzulinadás esetén az ebéd előtt), illetve - vacsora előtti inzulinadás esetén - a lefekvés előtt mért vércukorértékekkel ellenőrizték, s ezen vércukorértékek szolgáltak a hetenkénti dóziskorrekciókhoz is. Preprandialis kezelési célértékként a 3,9-6,1, lefekvéskor elérendő értékként a 3,9-7,1 mmol/l közötti tartományt határozták meg. Ez alatti esetben az aktuális adagot csökkentették, ellenkező esetben emelték (3. táblázat). Metformin és/vagy TZD-típusú szert a vizsgálatba vontak vé- 
gig szedhettek, inzulin secretagog készítmény azonban a bevezető szakaszt követően elhagyásra került. Az 1232 tesztelt személy közül 785 felelt meg a beválasztási feltételeknek, közülük 343 került randomizációra $(115,113$, illetve 115 fő a prandialis inzulint 1, 2, illetve 3 alkalommal kapó csoportba). Az első két csoportból 19, illetve 21 résztvevőt ki kellett zárni, a „kezelni tervezett” (intention-to-treat) csoportba így 101, 102, illetve 100 személy került. Közülük 16, 14, illetve 15 fő döntött a kezelés idő előtti abbahagyása mellett, így végül 85 , 88, illetve 85 személy adatait értékelték. A vizsgálat kimeneti végpontjaként a 24 . héten elért anyagcserekontrollt, az egyes csoportokon belül a $<7,0 \% \mathrm{HbA}_{1 c}$-értékre kerülők arányát, a kezelés alatti hypoglykaemiák gyakoriságát és a testsúly változását értékelték.

A bevezető szakasz végén az átlagos glargindózis $0,55 \mathrm{E} / \mathrm{kg}$ volt. A randomizációt követő átlagos $\mathrm{HbA}_{1 \mathrm{c}}$-változás az egyes csoportokban érdemben nem különbözött egymástól $\left(\Delta \mathrm{HbA}_{1 \mathrm{c}} 7,93 \rightarrow 7,44\right.$; $7,87 \rightarrow 7,40$, illetve $7,89 \rightarrow 7,29 \%$ ). A naponta 3 -szor prandialis inzulint kapók között nagyobb volt a $<7,0 \%$-ot elérők aránya (46 vs. 30 [,„bázis plusz” csoport], illetve $33 \%$ [a bázisinzulin mellett 2 glulisininjekciót kapó csoport]). A 24. hét végén a csoportonkénti átlagos glargindózis 88,88 , illetve $85 \mathrm{E}$, a glulisin adagja 28, 51, illetve $70 \mathrm{E}$ volt. Az eredmények azt mutatják, hogy mind a „bázis plusz”, mind a „bázis két plusz” kezelés egyszerü, biztonságos terápiás lehetőség. A tanulmánynak nem volt tárgya az egyes kezelési ágakból a másikba való átmenet vizsgálata. Annak bizonyítását szolgálta, hogy bázisinzulinhoz adott napi egy vagy két prandialis inzulinnal is jelentősen javítható az anyagcsere-állapot. A szerzők véleménye szerint az alkalmazott algoritmus jól segítheti az egyszeri prandialis inzulin napi 2 vagy 3 inzulinadásra való módosítását. ${ }^{17}$

Bázisinzulin kiegészítéseként adagolt prandialis inzulin két, beteg által irányított titrálási algoritmus eredményességét vizsgálta a multinacionális, multicentrikus, nyílt, párhuzamos csoportú, treat-to-target elvü AUTONOMY vizsgálat. (Az elnevezés ezúttal nem betűszó, a titrálással kapcsolatos önállóság/függetlenség kifejezésére utal.) E program tulajdonképpen két önálló vizsgálatot foglal magában: mind az A, mind a $\mathrm{B}$ jelű tanulmányban célértékre titrált glargin inzulinhoz szekvenciálisan bevezetett napi 1, 2 vagy 3 alkalommal adagolt prandialis (lispro) inzulin anyagcsere-javí-
3. táblázat. A prandialis inzulin adagjának hetenkénti változtatása célértéken lévő éhomi vércukorszintet $(<5,1 \mathrm{mmol} / \mathrm{l})$ biztosító bázisinzulin adagolás mellett Davidson és mtsai vizsgálatában ${ }^{18}$

\begin{tabular}{|c|c|c|}
\hline $\begin{array}{c}\text { Prandialis } \\
\text { adag (U) }\end{array}$ & $\begin{array}{c}\text { Alacsony } \\
\text { preprandialis érték } \\
\text { esetén követendö } \\
\text { dóziscsökkentés } \\
(\mathbf{S M B G} \geq \mathbf{2} \\
\text { alkalommal }<3,8 \\
\mathrm{mmol} / \mathrm{l})\end{array}$ & $\begin{array}{c}\text { Magas preprandialis } \\
\text { érték esetén } \\
\text { követendö } \\
\text { dózisemelés } \\
\text { (SMBG } \geq 4 \\
\text { alkalommal }>5,5 \\
\mathbf{m m o l} / \mathbf{l})\end{array}$ \\
\hline$\leq 10$ & $-1 \mathrm{E}$ & $+1 \mathrm{E}$ \\
\hline $11-20$ & $-2 \mathrm{E}$ & $+2 \mathrm{E}$ \\
\hline$>20$ & $-3 \mathrm{E}$ & $+3 \mathrm{E}$ \\
\hline
\end{tabular}

tó hatását elemezték, naponkénti (Q1 vizsgálat), illetve 3 naponkénti titrálási algoritmust (Q3 vizsgálat) összehasonlítva. Az A jelü tanulmányba 528, a B jelübe 578 T2DM-es személy került. ${ }^{19}$

E vizsgálatsorozatba olyan 18-80 év közötti, > 7,0 - $\leq 12,0 \%$ közötti $\mathrm{HbA}_{1 \mathrm{c}}$-értékkel rendelkező személyeket vontak be, akik addig $\geq 20$ E bázisinzulint (glargin, detemir, protaminizált lispro, NPH) és $\geq 3$ hónapja tablettás vércukorcsökkentőt kaptak (metformint, meglitinid-, sulfanylurea-csoportú szert, pioglitazont, sitagliptint vagy ezek kombinációját). Kizárási feltételként szerepelt gyors hatású humán inzulin vagy inzulinanalóg korábbi alkalmazása, jelentős mértékủ inzulinrezisztencia (inzulinigény $>2 \mathrm{E} / \mathrm{kg}$ ), morbid elhízás (BMI >45 $\mathrm{kg} / \mathrm{m}^{2}$ ), tervezett vagy fennálló terhesség, daganatos megbetegedés, kórelőzményben szereplő súlyos hypoglykaemia, mérsékelt/súlyos keringési/máj/vese/hematológiai megbetegedés. Nem kerülhettek a vizsgálatba azok sem, akik a bevonás előtti 3 hónapban GLP-1-receptor-agonista, alfa-glukozidáz-gátló, a sitagliptinen kívül más dipeptidilpeptidáz (DPP)-4-gátló vagy rosiglitazonkezelésben, 2 héten belül glucocorticoidterápiában részesültek. Azon személyek, akik a vizsgálatba vonást megelőzően is glargint kaptak és $\mathrm{HbA}_{1 \mathrm{c}}$-értékük $>7,0 \%$, éhomi vércukorszintjük $\leq 6,7 \mathrm{mmol} / \mathrm{l}$ volt, azonnal a Q1 vagy Q3 vizsgálat prandialis titrálási szakaszába kerültek. Azoknál, akik korábban más bázisinzulint adagoltak, glargin bevezetésére került sor, és az első 6 hétben orvos irányította a dózistitrálást az éhomi vércukorcélérték ( $\leq 5,5 \mathrm{mmol} / \mathrm{l})$ eléréséig. (Ugyanilyen hathetes glarginoptimalizáció történt azoknál is, akiknél az előzetes glarginkezelés mellett a $\mathrm{HbA}_{1 \mathrm{c}}>7,0 \%$, az éhomi vércukor $>6,7 \mathrm{mmol} / \mathrm{l}$ volt). Ezt követően kerülhetett a beteg a Q1 vagy Q3 szerinti titrálási csoportba. A lispro inzulin kezdőadagja a napi glargindózis $10 \%$-a volt. Azon sze- 
mélyek esetében, akik reggelit is fogyasztottak, az előtt került sor az első lispro inzulin beadására. Akiknél a reggeli kimaradt, az első napi étkezés előtt kezdték el a prandialis inzulin adását. A prandialis inzulin titrálási szakasza mindkét vizsgálati ágban 24 héten keresztül tartott. Azon esetekben, amikor egy prandialis inzulin adásával a következő étkezés preprandialis értékét dózistitrálást követően sem sikerült biztosítani, második, majd ha szükséges volt, egy harmadik étkezési bólus is alkalmazásra került. (A második és a harmadik prandialis bólus bevezetése előre nem volt pontosan meghatározva, azt minden esetben a kezelőorvos döntésére bízták: akkor kerülhetett rá sor, ha a preprandialis célértéket elérték ugyan, de a vércukorprofil nem volt kielégítő.)

Mindkét (A és B jelű) vizsgálat azt igazolta, hogy a naponkénti, illetve a háromnaponkénti önmenedzselt bólustitrálás közel azonosan hatékony. Az A vizsgálatban 3 naponkénti titrálással $-0,96 \%$, naponkénti titrálással $-1,0 \%$-os, a $\mathrm{B}$ jelü vizsgálatban -0,92, illetve $-0,98 \%$-os $\mathrm{HbA}_{1 \mathrm{c}}$-csökkenés volt elérhető. A betegek mintegy $61 \%$-ában $\leq 2$ prandialis injekcióval biztosítható volt az elöre meghatározott glykaemiás cél (azaz nem volt szükség a teljes bázis-bólus kezelés kezdeménye- zésére). A súlyos hypoglykaemia előfordulása alacsony és mindkét titrálási algoritmusban közel azonos volt. ${ }^{19}$

$\mathrm{Az}$ áttekintett adatok meggyőzően igazolják, hogy a „bázis plusz” kezelési koncepció a napszakos inzulinadásra áttérés hatékony bevezető fázisa. A bázisinzulin-titrálás nemzeti és nemzetközi ajánlásokban szereplő módozatait a 4. táblázatban, különböző vizsgálatokban igazolt eredményességű és biztonságú változatait az 5. táblázatban mutatjuk be. ${ }^{20} \mathrm{E}$ változatok valamelyikének segítségével, kellően edukált személyeken a bázisinzulin bevezetése és a titrálás egyszerűen és biztonságosan elvégezhető, célértéken lévő éhomi vércukor esetében pedig az étkezési inzulin(ok) hozzáadása is könnyen, akár önmenedzseléssel is megvalósítható (ennek egy lehetséges változatát szemlélteti a 3. táblázat).

\section{Premix inzulin lépcsőzetes bevezetése}

Az inzulinkezelés szekvenciális felépítésének másik lehetősége előkevert (premix: PM) inzulinana-

4. táblázat. Nemzeti és nemzetközi ajánlások a T2DM bázisinzulin-analóggal történő BOT kezelésének indítására és titrálására ${ }^{20}$

\begin{tabular}{|c|c|c|c|c|}
\hline \multirow{2}{*}{} & \multicolumn{4}{|c|}{ Ajánlott algoritmus } \\
\cline { 2 - 5 } & Kezdőadag & Titrálás & HbA $_{1 c}$-célérték (\%) & Éhomi vércukor (mmol/l) \\
\hline ADA/EASD & $10 \mathrm{E} /$ nap & $2 \mathrm{E} / 3$ naponta & $<7,0$ & $3,9-6,0$ \\
\hline AACE/ACE & $10 \mathrm{E} /$ nap & $1-3 \mathrm{E} / 2-3$ naponta & $\leq 6,5$ & $<5,5$ \\
\hline IDF & nincs meghatározva & $2 \mathrm{E} / 3$ naponta & $\leq 6,5$ & $<5,5$ \\
\hline CDA & $10 \mathrm{E} /$ nap & $1 \mathrm{E}$ naponta & $\leq 7,0$ & $4,0-7,0$ \\
\hline
\end{tabular}

\section{5. táblázat. Bázisinzulin bevezetése és titrálása különböző tanulmányokban ${ }^{21}$}

\begin{tabular}{|c|c|c|c|}
\hline \multirow{2}{*}{ INITIATE } & Kezdöadag & Titrálás menete & T́́homi vércukor (mmol/I) \\
\cline { 2 - 4 } & $10 \mathrm{E}$ & $2-4 \mathrm{E} / 3$ naponta & $4,0-5,5$ \\
\hline Treat-to-target vizsgálat & $10 \mathrm{E}$ & $2-8 \mathrm{E} / \mathrm{hét}$ & $\leq 5,5$ \\
\hline INSIGHT & $10 \mathrm{E}$ & $1 \mathrm{E} /$ nap & $<5,5$ \\
\hline LANMET & $10-20 \mathrm{E}$ & $2-4 \mathrm{E} / 3$ naponta & $4,0-5,5$ \\
\hline TITRATE & $10 \mathrm{E}$ & $*$ & $3,9-5,0 / 4,4-6,1$ \\
\hline Rosenstock és mtsai** & $12 \mathrm{E}$ & $-4-+12 \mathrm{E} /$ hét & $\leq 6,0$ \\
\hline
\end{tabular}

* Két éhomi célértéket határoztak meg: 3,9-5,0 mmol//-t kitǔzve, ha az éhomi érték <3,9 mmol/l volt a dózist 3 E-gel csökkentették, $>5,0$ mmol/l mérésekor viszont 3 E-gel emelték. Ugyanez 4,4-6,1 mmol/l célérték esetén $<4,4$, illetve $>6,1 \mathrm{mmol} \% /$ esetén volt alkalmazandó, minden esetben 3-3 napi értéket figyelembe véve. ** Rosenstock és mtsai hivatkozott tanulmánya detemir és glargin alkalmazását összevető 52 hetes treat-to-target tanulmány volt (Diabetologia 2008; 51: 408-416.) 
lóg bevezetése és az anyagcsere-állapothoz igazodó, napi 1-3 alkalommal történő adagolása. E kezelésforma bázis-bólus inzulinadással egyenértékű voltának igazolására korábban is voltak kísérletek, s noha az anyagcserekontroll jelentősen javult, a non-inferioritás tényét nem sikerült igazolni.

Rosenstock és $m$ tsai $\geq 30 \mathrm{E} /$ nap glargin és orális antidiabetikus kezelés mellett a kívánttól elmaradó anyagcsere-állapotú T2DM-es személyeken 24 hetes, nyílt, multicentrikus vizsgálatban 50:50 keverékarányú lispro mix napi háromszori adását (prandialis premix kezelés: PPT), illetve bázis-bólus kezelést (BBT) indítottak fokozatos dózisfelépítéssel, a $<6,0 \mathrm{mmol} / 1$ éhomi vércukorszintet célértékként meghatározva. Mindkét ágon intenzívebb (alkalmanként 4-20 E dózisemelés), illetve kevésbé intenzív titrálást (dózisemelés alkalmanként 2-10 E) alkalmaztak annak függvényében, hogy a napszakos inzulinadás előtti inzulinigény 100 E-nél nagyobb vagy kisebb volt. A kezelésváltást eredetileg 1:1 randomizációban tervezték, de a két-két titrálási alcsoportra tekintettel végül 1:1:1:1 arányban végezték. A PPT ágon mód volt a vacsora előtti 50:50 keverékarányú készítmény 25:75 arányúval való felváltására, ha a vércukormérések ezt indokolták. Az anyagcsere mindkét ágon jelentősen javult $\left(\Delta \mathrm{HbA}_{1 \mathrm{c}}\right.$ PPT ág: $8,8 \rightarrow 6,95 \%$, BBT kezelési ág: $8,9 \rightarrow 6,78 \%$ ), a non-inferioritás előre meghatározott mértékét $(0,3 \%)$ azonban PPT kezeléssel nem sikerült igazolni (a <7,0\% $\mathrm{HbA}_{1 \mathrm{c}}$-értéket elérők aránya a PPT csoportban 54 , a BBT ágon $69 \%$ volt). ${ }^{21}$

A várt eredmény elmaradásának lehetséges okait vizsgálva felmerült, hogy a PPT részeként magas keverékarányú készítményeket, esetleg nem megfelelő titrálást vagy túl rövid követési időt alkalmaztak. ${ }^{22}$ Ezen előzmények ismeretében került sor újabb prospektív tanulmányok indítására.

PM25 fokozatos bevezetésének, illetve a kontroll ágon glargin + lispro inzulin „bázis plusz” rendszerủ felépítésének eredményességét és biztonságát vizsgálta a 48 hetes, multinacionális, multicentrikus, nyílt, 1:1 randomizációjú PARADIGM vizsgálat.

A vizsgálatba olyan 30-80 éves, inzulinnaiv T2DM-es személyeket vontak be, akiknél a $\mathrm{HbA}_{1 \mathrm{c}}$-érték 7,0 és 11,0\% közötti, a BMI $\leq 35,0 \mathrm{~kg} / \mathrm{m}^{2}$ volt. Azon országokban, ahol pioglitazon inzulinnal együttadása nem volt engedélyezett, adását a randomizáció előtt két héttel leállították. A premix ágon a kezelést vacsora előtt adott 10 E PM25-tel (low mixture: lispro mix 25/75), a kontroll ágon lefekvéskor adagolt $10 \mathrm{E}$ glarginnal kezdték. Mindkét ágon 3-4 naponkénti dózistitrálást végeztek a $\leq 6,1 \mathrm{mmol} / \mathrm{l}$-es éhomi (illetve a későbbiekben az étkezések előtti) vércukorszint elérése céljából. A követés 12 hetes bevezető szakasszal indult (a glargin, illetve az első PM25-adag feltitrálása), ezt követően 6 hetente kerülhetett sor második, illetve harmadik injekció hozzáadásá$\mathrm{ra}$, ha a $\mathrm{HbA}_{1 \mathrm{c}}>7,0$ és a következő étkezés előtti vércukorszint célérték feletti maradt. A második PM25 inzulint reggel, a harmadikat - ha szükséges volt - a déli étkezés előtt adták. Amennyiben a glargin + lispro ágon a 24. héten is emelkedett maradt a harmadik étkezés (vacsora) előtti vércukorszint, a harmadik prandialis gyors hatású inzulin hozzáadására is sor került. Ezt követően további 24 héten keresztül követték a résztvevőket. A dózistitrálás a 6 hetes periódusokban az in-

6. táblázat. A 25/75 gyors/intermedier keverékarányú inzulin napi 1-2 vagy 3 alkalommal történö adagolása során alkalmazott algoritmus a PARADIGM vizsgálatban ${ }^{22}$

\begin{tabular}{|c|c|c|c|c|c|}
\hline \multicolumn{2}{|c|}{ PM25 1x } & \multicolumn{2}{|c|}{ PM25 2x* } & \multicolumn{2}{|c|}{ PM $253 x^{* *}$} \\
\hline $\begin{array}{l}\text { Éhomi vércukor } \\
\text { (mmol/l) }\end{array}$ & $\begin{array}{l}\text { Következö nap } \\
\text { vacsora elötti } \\
\text { inzulin dózisa (E) }\end{array}$ & $\begin{array}{l}\text { Vacsora elötti// } \\
\text { éhomi vércukor } \\
\text { (mmol/l) }\end{array}$ & $\begin{array}{l}\text { Következő nap } \\
\text { reggeli és esti } \\
\text { inzulin dózisa (E) }\end{array}$ & $\begin{array}{c}\text { Vacsora előtti } \\
\text { vércukor (mmol/l) }\end{array}$ & $\begin{array}{l}\text { Következőnap déli } \\
\text { inzulin dózisa (E) }\end{array}$ \\
\hline$<2,8$ & -4 & $<2,8$ & -4 & $<2,8$ & -3 \\
\hline $2,8-4,4$ & -2 & $2,8-4,4$ & -2 & $2,8-4,4$ & -2 \\
\hline $4,5-6,0$ & nincs változás & $4,5-6,0$ & nincs változás & $4,5-6,0$ & -1 \\
\hline $6,1-7,7$ & +2 & $6,1-7,7$ & +2 & $6,1-7,7$ & nincs változás \\
\hline $7,8-11,0$ & +4 & $7,8-11,0$ & +4 & $\geq 7,8$ & +2 \\
\hline$>11,0$ & +6 & & & & \\
\hline
\end{tabular}

Az első premix inzulin kezdődózisa 10 E volt. A dózistitrálás 3-4 naponta történt, a $\leq 6,1 \mathrm{mmol} / \mathrm{l}$ éhomi, illetve preprandialis vércukorszintet kezelési célként meghatározva.

* amennyiben 12 hét elteltével a $\mathrm{HbA}_{1 \mathrm{c}}>7,0 \%$ volt, reggeli előtt 15 perccel adagolva, második inzulin adását kezdték

** amennyiben további 8 hét elteltével a $\mathrm{HbA}_{1 \mathrm{c}}>7,0 \%$ volt, délben harmadik inzulin adását indították 
zulinadást követő étkezés előtti vércukorszint alapján, előre megadott algoritmus szerint történt. A PM25 titrálási algoritmusát a 6. táblázat szemlélteti (a „bázis plusz” kar titrálási menetének elve a már bemutatottaktól érdemben nem különbözött). A titrálást a kezelőorvos ellenőrzése mellett a résztvevők végezték: az első nyolc héten hetenkénti személyes, ezt követően kéthetenkénti telefonos konzultációk történtek.

Mindkét kezelési mód a glykaemiás kontroll hasonló mértékű, szignifikáns javulását eredményezte. $\mathrm{A} \mathrm{HbA}_{1 \mathrm{c}}$ a vizsgálat végpontjában a premix csoportban 8,98\%-ról 7,1\%-ra, a „bázis plusz” csoportban 9,03\%-ról 7,3\%-ra változott. A PM25 (lispro mix 25) ágon az inzulinadag $0,71 \pm 0,45$ (átlag $\pm \mathrm{SD}$ ), a másik ágon $0,71 \pm 0,47 \mathrm{E} / \mathrm{kg}$ volt. Nem volt eltérés a napi injekciók számában sem $(2,14 \pm 0,45$ vs. $2,25 \pm 1,2)$. Nem találtak eltérést sem az összes, sem az éjszakai, sem a súlyos hypoglykaemiák gyakoriságában. A két kezelés hatékonyságának és biztonságának non-inferioritása teljesült. ${ }^{22}$

Növekvő gyakoriságban, napi egyszer, illetve kétszer adagolt 25:75 vagy 30:70 keverékarányú előkevert inzulinanalóg és „bázis plusz” rendszerben adagolt glargin \pm glulisin glykaemiás kontrollra gyakorolt hatását elemezte az Insulin Glargine And gluLisine strAtegy vs. Premixed insulin strAteGy: a cOmparative Study (GALAPAGOS tanulmány). ${ }^{23}$

A 27 hetes nyílt, párhuzamos karú, több kontinensen zajló, multicentrikus, randomizált vizsgálatba $\geq 35$ éves, $<40 \mathrm{~kg} / \mathrm{m}^{2}$ BMI-vel rendelkező inzulinnaiv T2DM-es személyeket vontak be, akik ismert diabetestartama egy évnél nagyobb, $\mathrm{HbA}_{1 \mathrm{c}}$-értéke 7,0-10,0\% közötti volt. A vizsgálat értékelt szakasza az orális kezelés optimális adagjának meghatározására szolgáló kéthetes bevezető periódus után kezdődött és 24 héten keresztül tartott, lezárását követően a résztvevőket további egy héten keresztül követték. A második inzulininjekció bevezetéséig valamennyi addigi orális antidiabetikum a kezelés része maradt, azt követően az inzulin secretagog készítményeket leállították. A „bázis plusz” karon $(\mathrm{n}=462)$ az inzulinadagolást 0,2 E/kg (maximum $12 \mathrm{E}$ ) este adott glarginnal kezdték, amit 3 naponta dózistitrálással emeltek a $<5,6 \mathrm{mmol} / \mathrm{l}$-es éhomi vércukorszint eléréséig. Ha a 12 . héten a $\mathrm{HbA}_{1 \mathrm{c}} \geq 7,0 \%$ és/vagy az éhomi vércukor $\geq 7,0 \mathrm{mmol} / 1 \mathrm{maradt}$, a napi főétkezés előtt $4 \mathrm{E}$ kezdődózissal prandialis inzulint (glulisin) vezettek be, amelyet a háromnapi 2 órás pp. vércukorszint függvényében (célérték $<7,8 \mathrm{mmol} / \mathrm{l}$ ) titráltak. A premix ágon
( $\mathrm{n}=461)$ a kezelést vezetők döntése szerint napi egy vagy két inzulininjekciót adagoltak. Napi egy injekció választása esetén este 12 E-gel kezdték a kezelést, kétszeri adagolás esetén reggel és vacsora előtt 6-6 E-et adtak. Háromnaponkénti dózistitrálást alkalmaztak a 4,4-5,5 mmol/1 éhomi, illetve étkezés előtti vércukorszint elérésére. Azon betegek esetében, akik kezelését napi egy előkevert inzulinnal kezdték, a 24 hét során bármikor mód volt második premix inzulininjekció hozzáadására (a gyors:intermedier komponens arány azért változhatott 25:75, illetve 30:70 arányban, mert a részt vevő országok egy részében az eredetileg meghatározott összetételű készítmény nem állt rendelkezésre).

A két ág anyagcsereértékei a 24 . hét végén azonos mértékủ javulást mutattak. A premix csoportban valamivel többen érték el a $<7,0 \% \mathrm{HbA}_{1 \mathrm{c}}$-értéket (52,6 vs. 43,2\%, p=0,005), klinikai panaszt okozó hypoglykaemia viszont a „bázis plusz” karon volt ritkább (1,17 vs. 2,93 esemény/betegév). ${ }^{23}$

Hasonló következtetésre jutottak egy másik, 48 hetes, nyílt, párhuzamos karú vizsgálatban is, amely az előzőektől abban különbözött, hogy a premix ág $(\mathrm{n}=171)$ a magasabb pp. vércukorszint függvényében délben adott 50/50, illetve vacsora előtt alkalmazott 25/75 keverékarányú inzulin adagolásával is indulhatott. (A premix karon akkor is megengedett volt vacsora előtti inzulin elsőként való adása, ha az ebéd utáni pp. vércukorszint magasabb volt a vacsora utáninál, de az éhomi vércukor $\geq 8,0 \mathrm{mmol} / \mathrm{l}$ volt.)

Második PM50 (délben) vagy PM25 inzulin (vacsora előtt) bevezetésére került sor, ha 16/32 hét elteltével megfelelő dózistitrálással sem sikerült a $<7,0 \% \mathrm{HbA}_{1 \mathrm{c}}$-érték és/vagy a $<8,0 \mathrm{mmol} / \mathrm{l} 2$ órás pp. vércukorszintet elérni. Ha ezt követően sem sikerült megfelelő dózisváltoztatással a célértékeket biztosítani, reggeli előtt harmadik premix inzulininjekciót adtak, 25/75 vagy 50/50 keverékarányban az ebéd előtti vércukorszint függvényében. A másik ágon (n=173) a „bázis plusz” elv szerint folytatták az inzulinadagolást, a prandialis inzulinadagok számát szükség szerint napi háromig emelve (bázis-bólus kezelés).

Az anyagcsere mindkét karon jelentősen javult, a bevonási átlagosan 9,0, illetve 9,2\%-os értékről a premix ágon a $\mathrm{HbA}_{1 c}$ átlagosan 7,40, a másik karon 7,55\%-ra csökkent. A premix ágon a $<7,0 \%$ értéket elérők aránya nagyobb volt (48,2 vs. 36,2 ; $\mathrm{p}=0,024)$. A premix ágon lévők többsége csak két, 
déli és esti injekciót adagolt, mivel reggelire csak minimális szénhidrátmennyiséget fogyasztottak. $\mathrm{Az}$ önkontrollosan mért vércukorprofil-átlagok, a testsúlyváltozás, a napi inzulindózis és a hypoglykaemia gyakorisága a két csoportban közel azonos volt, kivéve az éjszakai vércukoresések előfordulását, amely a premix karon volt magasabb (34,3 vs. $23,7 ; \mathrm{p}=0,018) .{ }^{24}$

\section{Az irodalmi adatokból levonható követeztetések, a hazai alkalmazás lehetöségei}

A „bázis plusz” kezeléssel és annak bővítésével, illetve az előkevert inzulinanalógok fokozatos bevezetésével ez idő szerint kevés a hazai tapasztalat, aminek magyarázata döntő részben finanszírozási korlátokban keresendő. S noha kétségtelen, hogy egyik, 1,3,7,9,10,13,14,15,16,17 illetve másik kezelésfor$\mathrm{ma}^{22,23,24,25,26,27}$ fokozatos felépítéséről korábbról is rendelkezésre állnak közlések, a két alternatíva glykaemiás hatékonyságát, biztonságát összevető nemzetközi tapasztalatok is csak mostanában váltak szélesebb körben ismertté.

$\mathrm{Az}$ ismertetett vizsgálatokban orális antidiabetikus kezelést alkalmaztak bevonás előtt, GLP-1receptor-agonista nem szerepelt a kombinációkban. Ez jól magyarázható, hiszen akkor bázisinzulin hozzáadása - és nem a napszakos inzulinadás valamelyik formájának kezdeményezése - lett volna a legvalószínűbb terápiás lépés. Az alkalmazott vércukorcsökkentők között SGLT-2-gátló is csak elvétve szerepelt, ami ugyancsak nem meglepő, mivel e készítménycsoport csak a legutóbbi időben vált a terápiás eszköztár részévé. Az eredmények meggyőzően bizonyítják, hogy a jól felépített és a tolerált maximális dózisú orális kezelés ellenére a kívánttól elmaradó anyagcsere-állapotú T2DM-es személyeken a BOT prandialis inzulin hozzáadásával való lépcsőzetes kiegészítése vagy napi egy-két előkevert inzulinanalóg-injekció bevezetése jelentős javulást eredményez. A terápia bevezetése nem igényel kórházi elhelyezést, megfelelő dózisválasztás esetén a hypoglykaemiák kockázata alacsony, az esetek egy részében nincs szükség teljes dózisú napszakos inzulinadásra, rövidebb-hosszabb időre egy-két inzulininjekció is elfogadható glykaemiás kontrollt biztosíthat. A napjaink egészségügyi ellátásában egyre nagyobb jelentőségű költséghatékonyság elve tehát maximálisan teljesül.

E kezelésformák ugyanakkor kérdéseket is felvetnek. Egyfelől, a kezelést irányító teamnek kellő jártassággal kell rendelkeznie a titrálási folyamatban: még a beteg irányította dózisadaptáció esetén is elengedhetetlen a szoros ellenőrzés, elsősorban a titrálás korai szakaszában. Másfelől, nem látható előre, elegendő lesz-e egy vagy két injekció adása, vagy rövid időn belül át kell térni a teljes dózisú inzulinadagolásra. Ennek eldöntése a szokásosnál korábbi ellenőrzéseket, továbbá jól edukált, vércukor-önellenőrzést rendszeresen és kellő gyakorisággal végző, együttmüködő betegeket igényel. Figyelembe kell venni azt is, hogy bár ismertek $48,{ }^{22}$ illetve 52 hetes $^{26}$ vizsgálatok is, a tanulmányok nagyobb része 24-28 hetes követésű volt.

Kevés adat ismert arra vonatkozóan, hogy menynyi időre tolható ki lépcsőzetes bevezetéssel a teljes dózisú napszakos inzulinadás, s még nincsenek jól körvonalazott szempontok arra vonatkozóan, hogy mikor kerüljön sor premix, s mikor inkább a bázisinzulin, „bázis plusz” kezelés kezdeményezésére. Úgy tűnik, hogy két-háromszor adott premix inzulinnanalóggal és „bázis plusz” kezeléssel azonosan jó glykaemiás kontroll biztosítható, premixek adása mellett azonban gyakoribb a hypoglykaemia előfordulása és valamivel nagyobb a súlygyarapodás. ${ }^{22}$ Nem elhanyagolható szempont a követendő titrálási algoritmusok egyszerűbb vagy összetettebb volta sem, ami a komponensek külön-külön dozírozható voltából adódóan a bázisinzulinra épített prandialis inzulinok esetében könynyebben elsajátíthatónak látszik. Számításba kell venni természetesen azt is, hogy mindegyik kezelési forma esetében csak a követésbe vontak egy részén tartható fenn hosszabb időn keresztül a napi egy-két injekció, nagyobb részükben később napszakos inzulinadásra kell áttérni. ${ }^{28}$

E kezelésformák hazai gyakorlatunkban való megjelenése a finanszírozási előírások módosulása esetén várható. Előrelépést jelentene inzulinanalóggal végzett BOT után prandialis inzulinanalóg ugyancsak legalább 50\%-os támogatással engedélyezett rendelhetősége, illetve ha előkevert inzulinanalógok hasonló támogatással hozzáférhetővé válnának megelőző humán premix kezelés hiányában is. További lépésként jöhetne szóba a 100\%- 
os támogatás megadása, ha e kezelések legalább 6 hónapon keresztül kívánt glykaemiás kontrollt, $<7,0 \%$-os $\mathrm{HbA}_{1 c}$-értéket biztosítanak. A munkánkban bemutatott, igazolt hatékonyságú titrálási algoritmusok közreadása e kezelésformák hazai meghonosításának szándékával történt.

A kézirat leadását követően váltak online változatban hozzáférhetővé az ADA 2017. évi kezelési irányelvei. Ebben minimális mértékben módosult a bázisinzulin bevezetését követő terápiás lehetőségek algoritmusábrája, egyidejűleg megállapításra került, hogy a rendelkezésre álló vizsgálati eredmények alapján a bázisinzulin + GLP-1RA kombináció a bázisinzulin + prandialis inzulin kombinációval, illetve premix inzulin napi kétszeri adásával non-inferiornak véleményezhető.

\section{Köszönetnyilvánítás}

A közlemény megjelenését a Lilly Hungária Kft. támogatta. Az itt közölt információk a szerző véleményét tükrözik, ami eltérhet a Lilly Hungária Kft. álláspontjától.

A megemlített készítmények használatakor az érvényes alkalmazási előírás az irányadó.

Lezárás dátuma: 2017. február 27.

HUABA00033

\section{Irodalom}

1. Owens DR: Stepwise intensification of insulin therapy in type 2 diabetes management - exploring the concept of the basal-plus approach in clinical practice. Diabetic Med 2013; 30: 276-288. doi:10.1111/dme.12019

2. Cahn A, Miccoli R, Del Prato S: New forms of insulin and insulin therapies for the tre-atment of type 2 diabetes. Lancet Diabetes Endocrinol 2015; 3: 638-652. doi:10.1016/52213-8587(15)00097-2

3. Rodbard HW, Karolicki B: Management of type 2 diabetes - methods for addition of prandial to basal insulin. Eur Endocrinol 2014; 10: 124-130. doi:10.17925/EE.2014.10.02.124

4. Winkler G: Az antidiabetikus terápia lehetöségei BOT kezelés után 2-es típusú diabetes-ben. Diabetologia Hungarica 2016; 24: 15-22.

5. Khunti K, Wolden ML, Thorsted BL, Andersen M, Davies MJ: Clinical inertia in people with type 2 diabetes. A retrospective cohort study of more than 80,000 people. Diabetes care 2013; 36: 3411-3417. doi:10.2337/dc13-0331

6. Curtis B, Lage MJ: Glycemic control among patients with type 2 diabetes who initiate basal insulin: a retrospective cohort study. J Med Econ 2014; 17 : 21-31. doi:10.3111/13696998.2013.862538

7. Blak BT, Smith HT, Hards M, Curtis BH, IvanyiT: Optimization of insulin therapy in patients with type 2 diabetes mellitus: beyond basal insulin. Diabet Med 2012; 29: e13-e20. doi:10.1111/j.1464-5491.2012.03586.x

8. Peyrot M, Rubin RR, Lauritzen T, Skovlund SE,Snoek FJ, Matthews DR et al.: Resistance to insulin therapy among patients and providers: results of the cross national Diabetes At-titudes, Wishes and Needs (DAWN) study. Diabetes Care 2005; 28: 2673-2679. doi:10.2337/diacare.28.11.2673

9. Harris SB, Yale J-F, Berard L, Stewart J, Abbaszadeh B, Webster S et al:: Does a patient-managed insulin intensification strategy with insulin glargine and insulin glulisine pro-vide similar glycemic control as physician-managed strategy? Results of the START (Self-Titration with Apidra to Reach target) Study. A randomized noninferiority trial. Diabetes Care 2014; 37: 604-610. doi:10.2337/dc13-1636

10. Lankisch MR, Ferlinz K, Leahy JL, Scherbaum WA for the Orals Plus Apidra and Lantus (OPAL) Study Group: Introducing a simplified approach to insulin therapy in type 2 diabetes: a comparison of two single-dose regimens of insulin glulisine plus insulin glargine and oral antidiabetic drugs. Diabetes Obes Metab 2008; 10: 1178-1185. doi:10.1111/j.1463-1326.2008.00967.x

11. Inzucchi SE, Bergenstal RM, Buse JB, Diamant M, Ferrannini E, Nauck M et al: Mana-gement of hyperglycaemia in type 2 diabetes: a patient-centered approach. Position state-ment of the American Diabetes Association (ADA) and the European Association for the Study of Diabetes (EASD). Diabetologia 2012; 55: 1577-1596. doi:10.1007/s00125-012-2534-0

12. Inzucchi SE, Bergenstal RM, Buse JB, Diamant M, Ferrannini E, Nauck M et al: Management of hyperglycaemia in type 2 diabetes: a patient-centered approach, 2015. Update to a Position Statement of the American Diabetes Association (ADA) and the European Association for the Study of Diabetes (EASD). Diabetes Care 2015; 38: 140-149. doi:10.2337/dc14-2441

13. Rodbard HW, Visco VE, Andersen H, Hiort LC, Shu DHW: Treatment intensification with stepwise addition of prandial insulin aspart boluses compared with full basal-bolus therapy (FullSTEP Study): a randomised, treat-to-target clinical trial. Lancet Diabetes Endocrinol 2014; 2: 30-37. doi:10.1016/52213-8587(13)70090-1

14. Blonde L, Mersebach M, Karwe V, Raskin P, TITRATE Study Group: Patientdirected titration for achieving glycemic goals using a once-daily basal insulin analogue: an assess-ment of two different fasting plasma glucose targets - the TITRATE Study. Diabetes Obes Metab 2009; 11: 623-631. doi:10.1111/j.1463-1326.2009.01060.x 
15. Owens DR, Luzio SD, Sert-Langeron C, Riddle MC: Effects of initiation and titration of a single pre-prandial dose of insulin glulisine while continuing titrated insulin glargine in type 2 diabetes: a 6-month 'proof-of-concept' study. Diabetes Obes Metab 2011; 13: 1020-1027. doi:10.1111/j.1463-1326.2011.01459.x

16. Lankisch MR, Del Prato S, Dain M-P, Mullins P, Owens DR: Use of basal-plus insulin regime in persons with type 2 diabetes stratified by age and body mass index: a pooled analysis of four clinical trial. Primary Care Diabetes 2016; 10: 51-59. doi:10.1016/j.pcd.2015.05.003

17. Harris S, Yale JF, Dempsey E, Gerstein H: Can family physician help patients initiate basal insulin succesfully? Randomized trial of patient-titrated insulin glargine compared with standard oral therapy: lessons for family practice from the Canadian INSIGHT trial. Can Fam Physician 2008; 54: 550-558.

18. Davidson MB, Raskin P, Taneberg RJ, Vlajnic A, Hollander P: A stepwise approach to insulin therapy in patients with type 2 diabetes mellitus and basal insulin treatment failure. Endocr Pract 2011; 17: 395-403. doi:10.4158/EP10323.0R

19. Edelman SV, Liu R, Johnson J, Glass LC: AUTONOMY: the first randomized trial com-paring two patient-driven approaches to initiate and titrate prandial insulin lispro in type 2 diabetes. Diabetes Care 2014; 57: 2132-2140. doi: $10.2337 / \mathrm{dc} 13-2664$

20. LaSalle JR, Berria R: Insulin therapy in type 2 diabetes mellitus: a practical approach for primary care physicians and other health care professionals. J Am Osteopath Assoc 2013; 113: 152-162.

21. Rosenstock J, Ahmann AJ, Colon G, Scism-Bacon J, Jang H, Martin S: Advancing insulin therapy in type 2 diabetes previously treated with glargine plus oral agents. Diabetes Care 2008; 31: 20-25. doi:10.2337/dc07-1122

22. Bowering K, Reed VA, Felicio J, Landry J, Ji L, Oliveira J: A study comparing insulin lispro mix 25 with ghlargine plus lispro in patients with type 2 diabetes who have in-adequate glycemic control on oral antihyperglycaemic medication: results of the PARA-DIGM Study. Diabetic Med 2012; 29: e263-e272. doi:10.1111/j.1464-5491.2012.03722.x

23. Aschner P, Sethi B, Gomez-Peralta F, Landgraf W, Loizeau V, Dain M-P et al. Insulin glargine compared with premixed insulin for management of insulinnaive type 2 diabetes patients uncontrolled on oral antidiabetic drugs: the open-label randomized GA-LAPAGOS study. J Diab Compl 2015; 29: 838-845. doi:10.1016/j.jdiacomp.2015.04.003

24. Giugliano D, Tracz M, Shah S, Calle-Pascual A, Mistodie C, Duarte R et al. Initiation and gradual intensification of premixed insulin lispro therapy vs. basal \pm mealtime insulin in patients with type 2 diabetes eating light breakfests. Diabetes Care 2014; 37: 372-380. doi:10.2337/dc12-2704
25. Vora J, Cohen N, Evans M, Hockey A, Speight J, Whaley-Smith C: Intensifying insulin regimen after basal insulin optimisation in adults with type 2 diabetes: a 24-week rando-mised, open-label trial comparing insulin glargine plus insulin glulisine and biphasic insulin aspart (LanScape). Diabetes Obes Metab 2015; 17: 1133-1141. doi:10.1111/dom. 12528

26. Riddle MC, Rosenstock J, Vlajnic A, Gao L: Randomized 1-year comparison of three ways to initiate and advance insulin for type 2 diabetes: twice-daily premixed insulin ver-sus basal insulin with either basal-plus one prandial insulin or basal-bolus up to three pran-dial inhections. Diabetes Obes Metab 2014; 16(4):396-402. doi:10.1111/dom.12225

27. Tinahones FJ, Gross JL, Onaca A, Cleall S, Rodriguez A: Insulin lispro low mixture twice daily vs. basal insulin glargine once daily and prandial insulin lispro once daily in pati-ents with type 2 diabetes requiring insulin intensification: a randomized phase IV trial. Diabetes Obes Metab 2014; 16: 963-970. doi:10.1111/dom.12303

28. Downie M, Kilov G, Wong J: Initiation and intensification strategies in type 2 diabetes management: a comparison of basal plus and premix regimen. Diabetes Ther 2016; sept. 22. on-line, Doi:10.1007/s13300-016-0199-2 doi:10.1007/s13300-016-0199-2

29. ADA: Standards of medical care in diabetes -2017 . Chapter 8. Pharmacologic approa-ches to glycemic treatment. Diabetes Care 2017; 40(Suppl. 1): S64-S74. doi:10.2337/dc17-S011

Közlésre érkezett: 2016. november 23.

Közlésre elfogadva: 2017. március 1.

\section{A szerzö levelezési cime:}

\section{Dr. Winkler Gábor}

Szent János Kórház és Észak-budai Egyesített Intézményei, II. Belgyógyászat-Diabetológia

1125 Budapest, Diós árok 1-3.

E-mail: gabor.winkler@janoskorhaz.hu 